\title{
Determinants of Audit Committees Effectiveness in Enhancing Compliance With Regulations: Evidence From Saudi Context
}

\author{
Ali A. Alnodel \\ Associate Professor, Accounting Department \\ College of Business and Economics, Qassim University \\ P.O. Box 4667, Buraidah Qassim 51412, Saudi Arabia \\ E-mail: nodl@qu.edu.sa
}

Received: December 5, 2018 Accepted: December 22, 2018 Published: December 26, 2018

doi:10.5296/ijafr.v8i4.14002

URL: https://doi.org/10.5296/ijafr.v8i4.14002

\begin{abstract}
This paper aims to investigate how effective audit committees are in ensuring compliance with regulations in the Saudi context. Particularly, it examines whether there is an association between the value of fines imposed by the Saudi Capital Market Authority (CMA) and the size, frequency of meeting, and the financial expertise of the audit committee. Other variables have also been incorporated to control for possible effects, particularly size, leverage, ROA, age of the company, and year of fines. Data has been collected from the archives of CMA and from the annual reports of listed companies from 2014 to 2016. In total, 360 year-observations relating to 120 non-financial listed companies were analyzed among which 95 fines and actions imposed by CMA. The results suggest that the size and financial expertise of the audit committee and the leverage of the company and years of fines have significant association with the value of the fines imposed by CMA. In contrast, the regression analysis does not show significant association between the frequency of meeting of the audit committee and other controlled variables on the value of the fines imposed by CMA. These results suggest that the availability of resources to the audit committee, as suggested by the resource dependence theory, has a significant impact on its effectiveness. Regulators and companies could benefit from these findings to enhance compliance with regulations and to improve the role of audit committees. Moreover, these findings could be valuable to strengthen corporate governance practices in similar emerging markets.
\end{abstract}

Keywords: Audit committee, Corporate governance, Regulation compliance, Fines, Sanctions, Capital market 


\section{Introduction}

Corporate governance (CG) has become more complex and dynamic resulting in increased responsibilities for the board of directors and its committees. It determines the activities that are properly engaged and states the respective roles and responsibilities of the involved parties (Cadbury Report, 1992).One of the objectives of the CG system is to protect the company from fines and sanctions that might be imposed by the regulatory authorities. The CG system's ability to protect the company from violence of regulations depends upon the level of monitoring it provides, particularly on the board of directors and its committees. The board of directors is ultimately responsible for monitoring activities of firms and ensures compliance with regulations and recommended practices. Audit committee (AC) is the most frequently established committee by the board of directors. Regulations such as SOX in US and similar regulations adopted by other countries have emphasized this role (Brown et al., 2011).In the Saudi context, regulations of CG have also emphasized this role.CG regulations issued by CMA (2006) suggest that the purposes of AC are to help the board of directors in the oversight of the financial reporting process, the audit process, the company's system of internal controls, and compliance with laws and regulations. The effectiveness of AC in carrying out its responsibilities depends on the characteristics of AC (Herdjiono \& Sari 2017; Alqatamin, 2018). This paper aims to examine how effective AC is in ensuring compliance with CMA regulations in the Saudi context.

Evidence about the effectiveness of $\mathrm{AC}$ in ensuring compliance with regulations is significant to extend our understanding of the monitoring role of the CG systems as these systems differ from country to country, especially in developing countries and those where there is limited evidence about the role and effectiveness of structured committees (Brown, Beekes \& Verhoeven, 2011). In the Saudi context, AC and its effectiveness in ensuring compliance with regulations have received less attention from researchers. Most of those investigating AC focus on its impact on firm performance (e.g. Al-Matari, Al-Swidi, Fadzil, \& Al-Matari, 2012; Ghabayen, 2012), corporate disclosure (e.g. Al-Moataz \& Hussainey, 2012), quality of the financial reports (e.g. Rabab'ah, Al-Sir, \& Alzoubi, 2017), quality of external audit (Habbash, 2015), the role of audit committees (Al-Twaijry, Brierley \& Gwilliam, 2002), or its association with companies' CG system ( Al-Ruhaili, 2008).

The investigation of the effectiveness of $\mathrm{AC}$ is conducted by examining the association between the value of fines imposed by CMA and the size, frequency of meeting, and financial expertise of AC. The study also incorporates additional factors that might influence the value of fines imposed by CMA, particularly size, leverage, ROA, age of the company, and the year of fines imposed. The data for CMA fines is collected from CMA's archival and published annual reports of listed companies from 2014 to 2016. In total, 360 year-observations relating to 120 non-financial listed companies were analyzed among which 95 fines and actions were imposed by CMA.

This study is motivated by several grounds. First, this study is the first to examine fines and sanctions imposed by the Saudi CMA. Furthermore, this study utilizes a proxy for AC effectiveness in emerging markets which is different from self-structured index or surveys 
frequently adopted by researchers. This study is also motivated by the significance of broadening our understanding about regulation/governance performance which is considered an empirical issue of the CG system.

The rest of the paper is divided into eight sections. Sections 2 and 3 discuss previous studies and develop the hypothesis. Sections 4 and 5 describe research design and data collection. Sections 6 and 7 discuss results, and Section 8 provides the study's conclusion.

\section{Literature Review}

An extensive research has attempted to investigate whether there is an association between $\mathrm{AC}$ attributes and firm performance, firm transparency, earning management practices, accounting restatements, and fraud occurrence. These studies, however, reveal mixed findings concerning the relationship between $\mathrm{AC}$ attributes and the investigated issues. Further, limited studies have attempted to investigate the relationship between compliance with regulation and $\mathrm{AC}$ attributes especially in developing countries.

Among the most investigated issues is the relationship between AC characteristics and firm performance. Most of these studies have investigated the AC's value relevance to the firm's performance by examining the association between $\mathrm{AC}$ characteristics such as independence, size, frequency of meeting, and financial expertise with some proxies for firm performance. For instance, Bozec (2005) reported on an investigation of the association between AC characteristics and firm performance for firms listed in the Canadian Stock Exchange from 1976 to 2000. He found an association between the size of AC and the firm value. In US, Khanchel (2007) investigated whether there is a relationship between AC characteristics and company's performance using Tobin proxy-Q of 624 non-financial companies from 1994 to 2003. He reports a positive association between independence and size of AC and firm performance. Alqatamin (2018) reported in a study examining the effect of AC characteristics on a sample of 165 non-financial companies listed in the Jordanian stock market. He found that the AC size, independence, and gender diversity are positively associated with firm's performance. Similarly, Kallamu and Saat (2015) investigated whether AC attributes impact the performance of finance companies listed in the Malaysian stock market. They reported a significant positive association between independent attributes of $\mathrm{AC}$ and profitability and a negative association between the dual membership of directors on audit and nomination committee with profitability.

Other studies present different results. For instance, Al-Matari et al. (2012) reported noassociation between the sizes attributes of $\mathrm{AC}$ and firm performance of 135 firms listed in the Saudi stock market in 2011. Similarly, Ghabayen (2012) examined whether there is a relationship between the size and composition of $\mathrm{AC}$ and the size and composition of the board with the firm performance of 102 non-financial firms listed in the Saudi stock market in 2011. He reported no effect of the size and composition of AC and the size of the board and negative effect of board composition on firm performance measured by ROA. In an examination of the association between firm performance and characteristics of AC in non-financial companies listed in the Omani stock market during the period from 2011 to 2012, Al-Matari, Al-Swidi, and Fadzil (2014) reported positive non-significant association 
between the size and independence of $\mathrm{AC}$ and firm performance and negative relationship between AC meetings and firm performance. In a different environment, Hsu and Petchsakulwong (2010) examined the association between attributes of the AC and efficiency performance of Thai non-life insurance firms from 2000 to 2007 . They reported a negative association between the frequency of meeting of AC and efficiency performance.Chan, Lau, and $\mathrm{Ng}$ (2011) investigated the structural and operational characteristics of AC in Hong Kong by examining disclosure of 223 listed companies. They reported that the independence and financial expertise of $\mathrm{AC}$ have no influence on the value of firms because of inadequacy of the resources available to ACs.

From another vein, numerous studies have attempted to examine the link between the monitoring role of AC and firms' financial reporting and disclosure. For instance, Al-Moataz and Hussainey (2012) reported that board independence, AC size, company's liquidity, gearing, and profitability are crucial determinants of CG disclosure in Saudi's listed companies. In the UK, Peasnell, Pope, and Young (2001) investigated enforcement actions undertaken by the Financial Reporting Review Panel (FRRP). They reported that most firms being subject to such actions are less likely to have a good proportion of external directors and AC or to be audited by large audit firms. Similarly, in the US, Uzun, Szewczyk, and Varma (2004) found that the independence of the board of directors and its committees results in a lower level of corporate fraud. Furthermore, Abbott, Parker and Peters (2004) demonstrated that the financial background of AC is significant in reducing the occurrence of restatements, reporting a lower occurrence of restatements when there is at least one member of AC with a financial background.

Similar to this line of research, a number of studies have attempted to investigate the link between the effectiveness of AC and earnings management practices. For instance, Badolato, Donelson and Ege (2014) examined the impact of AC financial expertise on earning management in the US. Their study was based on a sample of 29,073 firm year-observations from 2001 to 2008. They found that AC with both financial expertise and high relative status reduces the levels of earnings management measured by accounting irregularities and abnormal accruals. Further, studies demonstrated that AC financial expertise limits earnings management practices (e.g. Bédard, Chtourou, \& Courteau, 2004; Dhaliwal, Naiker \& Navissi, 2010; Krishnan \& Visvanathan, 2008; Xie, DavidsonIII, \& DaDalt, 2003). Others have emphasized the significance of the independence of AC in enhancing the earning quality. From this line of argument, it was reported that AC independence influences the effectiveness of a monitoring role over earning quality and audit quality (Abbott \& Parker, 2000), enhances auditor independence (Abbott, Parker, Peters \& Raghunandan, 2003), and is associated with higher disclosure quality (Karamanou \& Vafeas, 2005). Others provide different perspectives. Reporting on a study of 347 fraud cases in US, Beasley, Carcello, Hermanson and Neal (2010) reported no difference between firms, irrespective of whether they were accused of fraud, with respect to their CG structures. Also, Rainsbury, Bradbury and Cahan (2009) reported no effects of AC quality on reporting quality or the audit fees paid. Song and Windram, (2004) explained that when members of board of directors are busy and directors' share of ownership is higher, AC's monitoring ability over financial reporting is constrained. 


\section{Ml Macrothink}

International Journal of Accounting and Financial Reporting

ISSN 2162-3082

2018, Vol. 8, No. 4

The association between the effectiveness of AC and the quality of internal control was also the subject for several studies. For example, Khlif and Samaha (2016) conducted a survey to examine the association between AC activities, external auditor's size and internal control quality among Egyptian companies. They reported a significant association between $\mathrm{AC}$ activities and internal control quality especially when the organization was audited by one of the big-four audit firms. Similarly, Krishnan (2005) reported lower likelihood of weakness of internal control with the increase of AC financial expertise. Coram, Ferguson and Moroney (2008) demonstrated an impact of the quality of AC on the effectiveness of internal control on detecting fraud and irregularities. Lee and Fargher (2018) investigated the oversight role of $\mathrm{AC}$ in whistle-blowing circumstances. They discovered that AC quality reflected by its independence, expertise, and diligence is associated with a system that enhances the reception and resolution of whistle-blowing disclosures through internal channels.

Overall, previous studies present evidence regarding whether the attributes of AC are important for firm performance and transparency or for constraining earning managements, accounting restatements, irregularities, and fraud occurrences. These studies, however, revealed mixed findings concerning the relationship between $\mathrm{AC}$ characteristics and the investigated issues. Furthermore, most of the studies investigating AC in the Saudi context focus AC's impact on firm performance (e.g. Al-Matari et al., 2012; Ghabayen, 2012), corporate disclosure (e.g. Al-Moataz \& Hussainey, 2012), quality of the financial reports (e.g. Rabab'ah et al., 2017), quality of external audit (Habbash, 2015), the role of audit committees (Al-Twaijry et al., 2002), its association with companies' CG systems (Al-Ruhaili, 2008), and the proposed relationship between AC, board of directors, and auditor independence (Bahrawe, Haron \& Hasan, 2016). To the researcher's best knowledge, there is no research investigating the surrounding circumstances of the CMA fines and actions and their link with the effectiveness of AC. This paper extends previous research by providing evidence confirming the effectiveness of $\mathrm{AC}$ on compliance with CMA regulations.

\section{Hypothesis Development}

The agency theory addresses the relationship between owners (principal) and company's management (agent). According to the agency theory, an agent acts on behalf of the principal and they should act in a way that maximizes the interest of the principal in accordance with their contractual agreement (Jensen \& Meckling, 1976). AC is fundamental in the monitoring role for the CG over the contractual agreement. In the Saudi context, CG regulations have also emphasized that one of the primary aims of $\mathrm{AC}$ is to ensure compliance with regulations and requirements (CMA, 2006). The effectiveness of AC's monitoring role depends, to some extent, on the characteristics of AC (Herdjiono \& Sari 2017; Alqatamin, 2018). There are a several attributes that have been reported to indicate the effectiveness of AC, particularly independence, size, financial expertise, gender diversity, and frequency of meeting. Due to the availability of data, this study focuses on three attributes: size, frequency of meetings, and financial expertise of AC. 


\section{Mll Macrothink}

International Journal of Accounting and Financial Reporting

ISSN 2162-3082

2018, Vol. 8, No. 4

\subsection{Audit Committee Size}

An AC should have enough members to be effective in carrying out its responsibilities. Herdjiono and Sari (2017) demonstrated that the size of the AC is an essential determinant of its effectiveness. The appropriate size of an AC is debatable. Dalton, Daily, Johnson and Ellstrand (1999) argued that an AC is less likely to be effective if it is too large or too small. The large size of AC could help in diversifying the experience and the background of the committee members. However, this would result in increasing the number of AC members which could result in loss of focus and less participation compared to a smaller one. On the other hand, a small-sized AC might help members concentrate and focus on the issues of the firm but will have less diversity in background, experience, skills, and knowledge. In the Saudi context, there is no specific requirement for the number of AC members, however, according to CMA regulations for $\mathrm{CG}$, an $\mathrm{AC}$ should have at least three members. Literature provides mixed results with respect to the impact of the size of AC on its effectiveness. Table 1 provides the summary of previous studies examining the impact of AC's size attribute.

Table 1. Studies examining the impact of the size attribute of AC

\begin{tabular}{|c|c|c|}
\hline Author \& Year & Dependent Variables & Findings \\
\hline $\begin{array}{l}\text { Pucheta-Martínez \& De Fuentes } \\
\text { (2007) }\end{array}$ & $\begin{array}{l}\text { The probability of companies receiving } \\
\text { audit reports containing errors or } \\
\text { non-compliant qualifications }\end{array}$ & + \\
\hline Khanchel (2007) & Firm's performance & + \\
\hline Alqatamin (2018) & Firm's performance & + \\
\hline Al-Moataz \& Hussainey (2012) & CG disclosure & + \\
\hline Hsu \& Petchsakulwong (2010) & Efficiency performance & - \\
\hline $\begin{array}{l}\text { Aldamen, } \quad \text { Duncan, Kelly, } \\
\text { McNamara \& Nagel (2012) }\end{array}$ & $\begin{array}{l}\text { The performance of the company } \\
\text { during financial crisis }\end{array}$ & - \\
\hline Krishnan (2005) & $\begin{array}{l}\text { Lower likelihood of weakness in } \\
\text { internal control }\end{array}$ & - \\
\hline Eichenseher and Shields (1985) & Firm performance & $=$ \\
\hline Menon \&Williams (1994) & Firm performance & $=$ \\
\hline Ghabayen (2012) & Firm performance & $=$ \\
\hline
\end{tabular}

(+) Positive, Negative (-), = No effect

Alqatamin (2018) argues that the positive relationship between AC size and the firm performance could be explained by the resource dependence theory which states that when the size of the committee increases, the available resources increase resulting in more effectiveness of the committee (Pearce \& Zahra, 1992). Accordingly, it can be postulated that when the number of $\mathrm{AC}$ members increases, it is likely that the $\mathrm{AC}$ will have better diversity 
of experience, expertise, and knowledge to better serve the interest of the firms and their stakeholders. Therefore, the value of fines imposed by CMA decreases as the number of AC members increases. Accordingly, the following hypothesis is developed:

H1: There is a significant negative association between the size of the audit committee and the value of fines/sanctions imposed by CMA.

\subsection{Frequency of Meeting of Audit Committee}

The AC's mentoring role could be influenced by the number of AC meetings per year. Vafeas, (1999) argued that the number of meetings of the board and its committees reflects its monitoring activities. When an AC meets more frequently, its members are more likely to be aware of the company affairs. Consequently, their monitoring role over the firm's transactions should be enhanced (Alqatamin, 2018). Nevertheless, the evidence reported in previous studies regarding the relationship between the frequency of AC meetings and its effectiveness is not conclusive. Table 2 summarizes previous studies' examination of the impact of the frequency of meeting aspect of ACs.

Table 2. Studies examining the impact of the frequency of meeting attribute of AC

\begin{tabular}{lll}
\hline Author \& Year & Dependent Variables & Findings \\
\hline Abbott et al. (2004) & $\begin{array}{l}\text { The likelihood of companies restating } \\
\text { their financial reports }\end{array}$ & + \\
\hline McMullen \& Raghunandan (1996) & Financial difficulties & - \\
\hline Xie et al.(2003) & Earning management & + \\
\hline Saleh, Iskandar \& Rahmat (2007) & Earning management & + \\
\hline Hsu \& Petchsakulwong (2010) & Efficiency performance & $=$ \\
\hline Alqatamin (2018) & Firm's performance & + \\
\hline
\end{tabular}

(+) Positive, Negative (-), = No effect

Similar to previous studies, this study incorporates the number of meetings per year as a proxy to measure the frequency of AC meetings (e.g. Xie et al., 2003; Lin, Li \&Yang, 2006; Alqatamin, 2018). It is presumed that the number of AC meetings reflects its monitoring effectiveness. Therefore, this would positively contribute to the role of $\mathrm{AC}$ in ensuring compliance with regulations. Accordingly, the following hypothesis is developed:

$\mathrm{H} 2$ : There is a significant negative relationship between the number of meetings of the audit committee and the value of fines/sanctions imposed by the CMA.

\subsection{Financial Expertise of Audit Committee}

Financial expertise reflects the technical financial background and experience of $\mathrm{AC}$ members. The capability of an AC to better serve the firm is likely to be higher if the committee members possess the necessary background and experience as they will be better 
in discussing, examining, and evaluating the relevant issues. To some extent, results from previous studies have supported the value relevance of financial expertise of AC. Table 3 summarizes previous studies' examination of the impact of the financial expertise attribute of $\mathrm{AC}$.

Table 3. Studies examining the impact of the financial expertise attribute of AC

\begin{tabular}{llc}
\hline Author \& Year & Dependent Variables & Findings \\
\hline Hamid \& Aziz (2012) & Firm's performance & + \\
\hline Abbott et al. (2004) & The occurrence of restatements & + \\
\hline Lee \& Fargher (2018) & Oversight of whistle-blowing system & + \\
\hline Carcello \& Neal (2003) & $\begin{array}{l}\text { Auditor dismissals following new } \\
\text { going - concern reports }\end{array}$ & + \\
\hline Bédard et al. (2004) & Earning management & + \\
\hline Saleh et al. (2007) & Earning management & + \\
\hline Dhaliwal et al. (2010) & Earning management & + \\
\hline Xie et al.(2003) & Earning management & + \\
\hline Krishnan and Visvanathan (2008) & Accounting conservatism & + \\
\hline Krishnan (2005) & $\begin{array}{l}\text { Lower likelihood of weakness in } \\
\text { internal control }\end{array}$ & + \\
\hline DavidsonIII, Xie \& Xu (2004) & Evaluation by market participants & + \\
\hline Abernathy, Herrmann, Kang \& & accuracy of analyst earnings forecasts & + \\
\hline Krishnan (2013) & $\begin{array}{l}\text { The performance of the company } \\
\text { during the financial crisis }\end{array}$ & - \\
\hline Aldamen et al. (2012) & & + \\
\hline
\end{tabular}

(+) Positive, Negative (-), = No effect

Badolato et al. (2014) argued that competence, ability, and authority of AC are critical to gain the respect of managers in order to influence financial reporting outcomes. In this study, an $\mathrm{AC}$ is classified as having financial expertise if their biographical information shows that one of the members has accounting and financial specialization. Accordingly, it can be assumed that an AC with financial expertise is better in protecting companies from fines imposed by CMA. Therefore, the following hypothesis is developed:

H3: There is a significant negative relationship between the financial expertise of the audit committee and the value of fines/sanctions imposed by the CMA.

To control for other factors that might influence the value of the fines or sanctions imposed by CMA, a number of factors have been incorporated into the model. The literature revealed 
that company attributes such as firm size, leverages, age, profitability, and year of the fines could be significant factors affecting the effectiveness of corporate governance (Saleh et al., 2007; Kallamu \& Saat, 2015; Alqatamin, 2018).

\section{Research Design}

One way to examine the effectiveness of an $\mathrm{AC}$ is to regress the value of fines or sanctions imposed by CMA on a company and the attributes of AC in the company. Accordingly, the dependent variable is the value of the fines or sanctions imposed by CMA. The value of the imposed fines or sanctions is more reliable than the number of imposed fines or sanctions because it measures the magnitude of the violation and avoids any possible misinterpretation of the action taken by CMA. Independent variables are measured as shown in Table 4. Accordingly, the following empirical model is formulated to investigate the effectiveness of $\mathrm{AC}$ in protecting companies from fines or sanctions imposed by CMA.

$$
\begin{aligned}
\text { VFSit } & =\beta 0+\beta 1 \text { ACSIZit }+\beta 2 \text { ACFMit }+\beta 3 \text { ACFEit }+\beta 4 \text { SIZEit }+\beta 5 \text { LEVERit } \\
& +\beta 6 \text { ROAit }+\beta \text { AGEit }+ \text { Year Controls }+\varepsilon I
\end{aligned}
$$

\begin{tabular}{|c|c|c|}
\hline Label & Variables & Description \\
\hline VFS & Value of Fines or Sanctions & $\begin{array}{l}\text { Value of fines or sanction imposed by } \\
\text { CMA at year-end }\end{array}$ \\
\hline ACSIZ & Size of Audit Committee & Total number of audit committee members \\
\hline $\mathrm{ACFM}$ & $\begin{array}{l}\text { Meeting Frequency of } \\
\text { Audit Committee }\end{array}$ & $\begin{array}{l}\text { Number of audit committee meetings held } \\
\text { during the year }\end{array}$ \\
\hline ACFE & $\begin{array}{l}\text { Financial Expertise of } \\
\text { Audit Committee }\end{array}$ & $\begin{array}{l}\text { A dummy variable that takes the value of } \\
1 \text { when one member of the audit } \\
\text { committee has financial background and } 0 \\
\text { otherwise }\end{array}$ \\
\hline SIZE & $\begin{array}{l}\text { Company Log. Of Total } \\
\text { Assets }\end{array}$ & The natural log of a firm's total assets. \\
\hline LEVER & Company Leverages & Total liabilities divided by total assets \\
\hline ROA & $\begin{array}{l}\text { Company Retained on } \\
\text { Assets }\end{array}$ & $\begin{array}{l}\text { Net Profit before tax at the year-end } \\
\text { divided by total assets }\end{array}$ \\
\hline AGE & $\begin{array}{l}\text { Company Age since } \\
\text { establishment }\end{array}$ & $\begin{array}{l}\text { Number of years at the year-end since } \\
\text { establishment }\end{array}$ \\
\hline Year Controls & Year of the Fines & $\begin{array}{l}\text { Year where the fines or sanctions have been } \\
\text { imposed }\end{array}$ \\
\hline
\end{tabular}

Table 4. Variables definition and description 


\section{Macrothink \\ International Journal of Accounting and Financial Reporting \\ ISSN 2162-3082 \\ 2018, Vol. 8, No. 4}

\section{Sample and Date Collection}

This study's data relates to all non-financial companies listed in the Saudi stock market through the period from 2014 to 2016. At the end of 2016,130 non-financial companies were listed. Nine companies were excluded from the study because they were not listed during the whole period. Further, one telecommunication company was excluded because the data for its fines was not identified. These lift 120 companies covered by this study with 360 year of observations.

The data covers all fines imposed by CMA during the period from 2014 to 2016 and was collected from the Saudi Stock Exchange Company (Tadawul) website. CMA promptly announces any fines/sanction imposed on any listed companies on the Tadawul website. Each announcement describes the nature of violation, the irregularity or misconduct that has been identified, its dates, and CMA's decisions regarding the value and time of fines/sanction. Data relating to other variables of the study was collected from the annual report of each company listed in the Saudi stock exchange. Relying on these sources for collecting the necessary data is justifiable. These sources are official and present the primary sources for such data. Data about fines/sanctions imposed on companies directly reflects or proxies the effectiveness of their ACs' monitoring roles in ensuring compliance with irregularities and best practices. Previous studies have utilized similar data in evaluating the effectiveness of AC (e.g. Abbott et al., 2004; Peasnell et al., 2001).

\section{Descriptive Statistics}

During the period of the study, the total value of fines imposed by CMA on listed non-financial companies because of violation is approximately SR 5,050,000. These fines range from SR 320,000 to SR 10,000 and the total number of actions were approximately 95. The mean of the fines were about (SR 14,027.78). Of the total 120 non-financial companies, $45(37.5 \%)$ received no fines and $75(62.5 \%)$ were subject to fines in any year of the three years under study. Table 5 shows the descriptive statistics of the dependent and independent variables. Descriptive statistics of the independent variables reveal that the size of AC ranges from three to six members and the mean is about 3.42. The number of AC meetings varies from one to sixteen meetings during the year. Furthermore, the mean for the number of meetings is about 5.71 times. Table 5 shows further descriptive statistics of the study sample. 
Table 5. Descriptive statistics

\begin{tabular}{|c|c|c|c|c|}
\hline & Minimum & Maximum & Mean & Std. Deviation \\
\hline VFS & 0 & 320000 & 14027.78 & 37611.847 \\
\hline ACSIZ & 3 & 6 & 3.42 & .671 \\
\hline ACFM & 1 & 16 & 5.71 & 2.037 \\
\hline SIZE & 11.27 & 19.81 & 14.7170 & 1.55557 \\
\hline LEVER & .0132 & .9604 & .407809 & .2221406 \\
\hline $\mathrm{ROA}$ & -.5118 & .3614 & .056925 & .0901020 \\
\hline AGE & 1 & 66 & 27.58 & 14.324 \\
\hline \multicolumn{5}{|c|}{ Year Controls } \\
\hline 2014 & 0.00 & 320,000 & 24500 & 42857.003 \\
\hline 2015 & 0.00 & 320,000 & 14666 & 43885.514 \\
\hline \multirow[t]{2}{*}{2016} & 0.00 & 140,000 & 2916 & 16418.673 \\
\hline & Frequency & $\%$ & & \\
\hline \multicolumn{5}{|l|}{ ACFE } \\
\hline Yes & $265(88)$ & 73.6 & & \\
\hline No & $95(31)$ & 26.4 & & \\
\hline
\end{tabular}

The Variables' Definitions are as in Table 4.

\section{Regression Results}

The regression is statistically significant with a high F-value and low significance probability of $\mathrm{F}$. The multiple regression model with all predictors produced $\mathrm{R}^{2}=.186$ and adjusted $\mathrm{R}^{2}=.168, \mathrm{~F}(8,351)=10.054, \mathrm{p}<.000$. The coefficient of determination is 19 percent which is informative considering the type of the data. For checking the OLS assumptions, appropriate tests are applied. Normality and linearity of the data are approved, and no multicollinearity was detected given that the Tolerance and VIF are within the acceptable levels. There are no errors in variables and autocorrelation (Durbin-Watson $=2.052$ ). The regression results are obtained using SPSS and summarized in Table 6. 
Table 6. Regression results

\begin{tabular}{|c|c|c|c|c|c|c|c|}
\hline & \multicolumn{2}{|c|}{$\begin{array}{l}\text { Unstandardized } \\
\text { Coefficients }\end{array}$} & \multirow{2}{*}{$\begin{array}{l}\text { Standardized } \\
\text { Coefficients } \\
\text { Beta }\end{array}$} & \multirow[b]{2}{*}{$\mathrm{t}$} & \multirow[b]{2}{*}{ Sig. } & \multicolumn{2}{|c|}{$\begin{array}{l}\text { Collinearity } \\
\text { Statistics }\end{array}$} \\
\hline & B & Std. Error & & & & Tolerance & VIF \\
\hline (Constant) & 54132.006 & 13282.614 & & 4.075 & .000 & & \\
\hline ACSIZ & -3258.931 & 1832.188 & -.128 & -1.779 & .076 & .448 & 2.230 \\
\hline ACFM & -955.259 & 627.104 & -.081 & -1.523 & .129 & .828 & 1.208 \\
\hline ACFE & -9165.350 & 2705.503 & -.195 & -3.388 & .001 & .700 & 1.429 \\
\hline SIZE & -956.307 & 1018.106 & -.073 & -.939 & .348 & .388 & 2.575 \\
\hline LEVER & 19317.247 & 8969.681 & .170 & 2.154 & .032 & .372 & 2.686 \\
\hline ROA & -9061.437 & 29711.147 & -.020 & -.305 & .761 & .527 & 1.896 \\
\hline AGE & 100.597 & 114.858 & .055 & .876 & .382 & .579 & 1.726 \\
\hline $\begin{array}{l}\text { Year } \\
\text { Controls }\end{array}$ & -9196.504 & 1372.627 & -.329 & -6.700 & .000 & .963 & 1.039 \\
\hline
\end{tabular}

a. Dependent Variable: Value of fines

b. Linear Regression through the Origin

Note: $* * *, * *$ and $*$ statistically significant at $1 \%, 5 \%$ and $10 \%$, respectively.

The Variables' Definitions are as in Table 4.

The results of standardized coefficients show the relative impact of the independent variables on the dependent variable. According to the results, year of fines has the highest impact on the value of fines imposed by CMA followed by financial background, leverage, and AC meeting. The coefficients of the rest of the variables are either very small or statistically insignificant.

The role of $\mathrm{AC}$ on enhancing compliance with regulations is the primary focus of this study. The same has been incorporated into the study to investigate whether the size, number of meetings, and financial background of AC affect the value of the fines imposed by CMA. The results show that all these variables have a negative relationship with the value of fines imposed by CMA, suggesting that the increase in the size, number of AC meetings, and the presence of financial background among members lead to a decrease in the value of fines 
imposed by CMA. These results suggest that AC could contribute to the value of the company by enhancing compliance with regulations of CMA.

Among the various AC attributes, the financial background of members is the most influential factor. According to the regression results, the coefficient of the variable is negative and statistically significant as hypothesized. The possible interpretation is that background and knowledge in accounting and financial field could enhance the monitoring role of AC which would lead to lower values of fines imposed by regulators. This result is consistent with the argument of Abbott et al., (2004) who reported that the financial background of AC is important in reducing the occurrence of restatements, reporting a lower occurrence of restatements. Moreover, Aldamen et al. (2012) reported that smaller committees with more experience and financial expertise contribute positively to the performance of the company during financial crisis. This could be explained by the resource dependence theory, proposing that the effectiveness of committees will be enhanced when experience and knowledge is diversified (Pearce \& Zahra, 1992).

Furthermore, the size of $\mathrm{AC}$ has a negative effect on the value of the fines imposed by CMA and is statistically significant at $10 \%$. This suggests that when the number of AC members increases, the value of the fines imposed by the CMA decreases. This reflects the adding value that more members in AC could contribute to the company by enhancing diversity in experience and knowledge (Dalton et al., 1999). According to the resource dependence theory, when the size of the committee increases, the available resources such as diversity of experience, knowledge, and background increases which results in more effectiveness in carrying out responsibilities (Pearce \& Zahra, 1992). Previous studies have reported similar results, demonstrating the importance of the size of AC in determining its effectiveness (Herdjiono \& Sari, 2017), reporting an association between AC size and the probability of companies receiving audit reports containing errors or non-compliant qualifications (Pucheta-Martínez \& De Fuentes, 2007) and a significant association between company performance and AC size (Alqatamin, 2018). Adversely, these results do not support the findings, reporting no significant association between AC size and firm performance (Eichenseher \& Shields, 1985; Menon \&Williams, 1994).

The third variable relating to $\mathrm{AC}$ is the number of $\mathrm{AC}$ meetings which represents how often the company AC conducts its meetings per year. According to the regression results, the coefficient of this variable is negative and statistically insignificant. This suggests that when the number of AC meetings increases, the value of the fines imposed by CMA decreases but this association is insignificant. Therefore, it does not support the study hypothesis. Previous studies on the impact of the number of meetings on AC effectiveness provide mixed results. The results of this study support the findings of Alqatamin, (2018) reporting no significant association between the number of AC meetings and the company performance. In contrast, these results do not support the findings of other studies, demonstrating an association between the number of AC meetings and its effectiveness (Abbott et al., 2004; McMullen \& Raghunandan, 1996).

Other factors that have been incorporated into the study to control for their impact on the 
value of the fines imposed by CMA relate to the year of fines and the company attributes, especially size, leverage, ROA and age of the company. Among these later variables, only two variables proved to be statistically significant which are the year of the fines and the company's leverage. According to the regression results, the coefficient of the variable the year of fines is negative and statistically significant as expected. This result suggests that during the early years of the study, firms were subject to more fines and actions from CMA. This is logical since during 2014, more fines were imposed by CMA as a result of initiating new requirements for disclosure and transparency where companies were not yet orientated for such regulations. To illustrate, the mean for the value of fines imposed during these years are (SR 24,500), (SR 14,666) and (SR 2,916) in 2014, 2015, and 2016, respectively. This decrease in the value of the fines imposed by CMA is likely representing the learning curve of the listed companies as the Saudi stock market is one of the emerging stock exchanges.

Leverage (Total Debt to Total Assets) ratio of the firm's capital structure at the end of each year indicates the degree of risk of the firm and is expected to have a positive effect on the value of the fines imposed by the CMA. The regression results of the coefficient of D/A ratio are positive and statistically significant, suggesting that when the leverage of the firm measured as D/A increases, the value of the fines imposed by CMA increases. These could be interpreted as the riskier firms are more likely to violate regulations because such firms are under higher pressure to meet their financing requirements. Previous studies have reported similar concerns. For instance, Loebbecke, Einingand and Willingham (1989) argued that motivations, attitude, and opportunities represent three prevailing conditions that facilitate irregularities, fraud, and misinformation.

In contrast to the above variables, the regression analysis does not show significant association between the variables of size, ROA and age of the company and the value of the fines imposed by CMA. These results suggest that non financial firms are subject to fines and sanctions irrespective to their size, profitability and age. This might be explained by the nature of the investigated issue in this study which is a compulsory or mandatory compliance. Thus company attributes would have lees effect on such compliance.

To sum up, the multiple regression results show that $\mathrm{AC}$ has a significant role in compliance with regulations. However, its effectiveness depends on its attributes, particularly accounting and financial expertise and size. This could be explained by the resource dependence theory proposing that the effectiveness of committees will be enhanced as the available external resources increase such as the number of members and experience and knowledge are diversified (Pearce and Zahra, 1992).

\section{Conclusion}

This study investigates determinants of the effectiveness of AC in enhancing compliance with regulations. The investigation of the effectiveness of the monitoring role of $\mathrm{AC}$ is conducted by examining the association between the value of fines imposed by CMA and AC attributes (size, frequency of meeting, and financial expertise). The study also incorporates additional factors that might influence the value of fines imposed by CMA, particularly size, leverage, ROA, age of the company, and the year of fines imposed. The data for CMA fines is collected 
from CMA's archival and published annual reports of listed companies from 2014 to 2016. In total, 360 year-observations relating to 120 non-financial listed companies were analyzed among which 95 fines and actions were imposed by CMA.

Out of these eight factors, four important factors were revealed to be statistically significant. The results of standardized coefficients suggest that the size and financial expertise of AC, the leverage of company and the year of fines are associated with the values of fines imposed by CMA. The most important result is that the role of AC in enhancing compliance with regulations is likely to be improved when the number and financial expertise of $\mathrm{AC}$ is increased. These results are consistent with the results reporting the importance of AC size (e.g. Herdjiono \& Sari, 2017; Pucheta-Martínez \& De Fuentes, 2007; Alqatamin, 2018) and the importance of AC financial expertise (e.g. Abbott et al. 2004; Aldamen et al., 2012).

This could be explained by the resource dependence theory which states that a corporation is an open system depending on its external environment, and regulated environment corporations need more outsiders with more relevant experience (Pfeffer \& Salancik, 1978). According to Hillman and Dalziel, (2009) the role of monitoring as proposed by the agency theory and resource provision as proposed by the resource dependence theory are important functions of the corporation board. Several previous studies examining AC also support the resource dependence theory by reporting a positive relationship between AC diversity and firm performance (e.g. Reddy, Locke \& Scrimgeour, 2010; Al-Matari et al., 2012). Therefore, it could be concluded that the resource dependence theory might provide further explanation regarding the role and contributions of AC in the context of the Saudi market as an emerging stock market.

These results should be beneficial to regulators, stakeholders, and researchers. Regulators might benefit from these results by strengthening regulations relating to the formation of AC in Saudi firms. Stakeholders and investors should support diversity of AC to enhance compliance with regulations. This study examined the relationship between AC attributes and compliance with regulations. Future research might examine this issue with respect to the board of directors' characteristics in order to examine the overall value relevance of corporate governance. Furthermore, other studies could employ different proxies or research methods or examine the issues in different emerging markets. Some limitations should be considered by readers particularly reliance on the published reports which might be given limited information about AC attributes and the emerging nature of the Saudi stock market which could influence the attitude of the regulatory body.

\section{References}

Abbott, L. J., \& Parker, S. (2000). Auditor selection and audit committee characteristics. Auditing: A Journal of Practice and Theory, 19(2), 47-66.

Abbott, L. J., Parker, S., \& Peters, G. F. (2004). Audit Committee Characteristics and Restatements. Auditing: A Journal of Practice and Theory, 23(1), 69-87.

Abbott, L. J., Parker, S., Peters, G. F., \& Raghunandan, K. (2003). An empirical investigation of audit fees, non-audit fees, and audit committees. Contemporary Accounting 
Research, 20(2), 215-234.

Abernathy, J. L., Herrmann, D., Kang, T., \& Krishnan, G. V. (2013). Audit committee financial expertise and properties of analyst earnings forecasts. Advances in Accounting, 29(1), 1-11.

Aldamen, H., Duncan, K., Kelly, S., McNamara, R., \& Nagel, S. (2012). Audit committee characteristics and firm performance during the global financial crisis. Accounting and Finance, 5(24), 971-1000.

Al-Matari E. M., Al-Swidi A. K., \& Fadzil, F. H. B. (2014). Audit committee characteristics and executive committee characteristics and firm performance in Oman: empirical study. Asian Social Science, 10(12), 98-113.

Al-Matari, Y. A., Al-Swidi, A. K., Fadzil, F. H. B., \& Al-Matari, E. M. (2012). Board of directors, audit committee characteristics and the performance of Saudi Arabia listed companies. International Review of Management and Marketing, 2(4), 241-251.

Al-Moataz, E., \& Hussainey, K. (2012). Determinants of corporate governance disclosure in Saudi Arabia. King Abdulaziz University Journal of Economics and Administration, 27(2), 411-430.

Alqatamin, R. M. (2018). Audit committee effectiveness and company performance: evidence from Jordan. Accounting and Finance Research, 7(2), 48-60.

Al-Ruhaili, A. (2008). Audit committees as a pillar of corporate governance: Saudi case. King Abdulaziz University Journal of Economics and Administration, 22(1), 179-218.

Al-Twaijry, M., Brierley, A., \& Gwilliam, R. (2002). An examination of the role of audit committees in the Saudi Arabian corporate sector. Corporate Governance: An International Review, 10(4), 288-297.

Badolato, P. G., Donelson, D. C., \& Ege, M. (2014). Audit committee financial expertise and earnings management: the role of status. Journal of Accounting and Economics, 58(2-3), 208-230.

Bahrawe, S. H., Haron, M. H., \& Hasan, A. N. (2016). Corporate governance and auditor independence in Saudi Arabia: literature review and proposed conceptual framework. International Business Research, 9(11), 1-15.

Beasley, M. S., Carcello, J. V., Hermanson, D. R., \& Neal, T. L. (2010). Fraudulent Financial Reporting: 1998-2007. An analysis of US public companies, committee of sponsoring organizations of the tread way commission, Durham, North Carolina, US. Retrieved April 27, 2017, from https://www.coso.org/Documents/COSO-Fraud-Study-2010-001.pdf

Bédard, J., Chtourou, S. M., \&Courteau, L. (2004). The effect of audit committee expertise, independence, and activity on aggressive earnings management. Auditing: A Journal of Practice and Theory, 23(2), 13-35.

Bozec, R. (2005). Boards of directors, market discipline and firm performance. Journal of Business Finance and Accounting, 32(9-10), 1921-1960. 


\section{MInstitute ${ }^{\text {Macrothink }}$}

International Journal of Accounting and Financial Reporting

ISSN 2162-3082

2018, Vol. 8, No. 4

Brown, P., Beekes, W., \& Verhoeven, P. (2011). Corporate governance, accounting and finance: A review. Accounting and Finance, 51(1), 96-172.

Cadbury Report. (1992). Report of the Committee on the Financial Aspects of Corporate Governance (Gee, London). Retrieved April 10, 2017, from http://www.ecgi.org/codes/documents/cadbury.pdf

Capital Market Authority (CMA). (2006). Corporate Governance Regulations. (Riyadh, Saudi Arabia) Retrieved March 5, 2017, from https://cma.org.sa/en/RulesRegulations/Regulations/Documents/CGRegulations_en.pdf

Carcello, J. V., \& Neal, T. L. (2003). Audit committee characteristics and auditor dismissals following new going-concern reports. The Accounting Review, 78(1), 95-117.

Chan, R. S. Y., Lau, C. K. S., \& Ng, A. W. (2011). Compliance and value relevance of audit committees: evidence from Hong Kong. Journal of Financial Reporting and Accounting, 9(1), 74-97.

Coram, P., Ferguson, C., \& Moroney, R. (2008). Internal audit, alternative internal audit structures and the level of misappropriation of assets fraud. Accounting and Finance, 48(4), 543-559.

Dalton, D. R., Daily, C. M., Johnson, J. L., \& Ellstrand, A. E. (1999). Number of directors and financial performance: A meta-analysis. The Academy of Management Journal, 42(6), 674-686.

DavidsonIII, W. N., Xie, B., \& Xu, W. (2004). Market reaction to voluntary announcements of audit committee appointments: The effect of financial expertise. Journal of Accounting and Public Policy, 23(4), 279-293.

Dhaliwal, D., Naiker, V., \& Navissi, F. (2010). The association between accruals quality and the characteristics of accounting experts and mix of expertise on audit committees. Contemporary Accounting Research, 27(3), 787-827.

Eichenseher, J. W., \& Shields, D. (1985). Corporate director liability and monitoring preferences. Journal of Accounting and Public Policy, 4(1), 13-31.

Ghabayen, M. A. (2012). Board characteristics and firm performance: case of Saudi Arabia. International Journal of Accounting and Financial Reporting, 2(2), 168-200.

Habbash, M. (2015). Audit committee effectiveness and audit quality: evidence from Saudi Arabia. International Journal of Management and Applied Science, 1(7), 5-14.

Hamid, A., \& Aziz, R. (2012). Impact of the amendments of Malaysian code of corporate governance (2007) on governance of GLCs and performance. International Journal of Economics and Management Engineering, 6(11), 3181-3186.

Herdjiono, I., \& Sari, I. M. (2017). The effect of corporate governance on the performance of a company. Some empirical findings from Indonesia. Journal of Management and Business Administration, 25(1), 33-52.

Hillman, A. J., Withers, M. C., \& Collins, B. J. (2009). Resource dependence theory: a 
review. Journal of Management, 35(6), 1404-1427.

Hsu, W. Y., \& Petchsakulwong, P. (2010). The impact of corporate governance on the efficiency performance of the Thai non-life insurance industry. Geneva Papers on Risk and Insurance - Issues and Practice, 35(1), S28-S49.

Jensen, M. C., \& Meckling, W. H. (1976). Theory of the firm: managerial behaviour, agency costs and ownership structure. Journal of Financial Economics, 3(4), 305-360.

Kallamu, B. S., \& Saat, N. A. M. (2015). Audit committee attributes and firm performance: evidence from Malaysian finance companies. Asian Review of Accounting, 23(3), 206-231.

Karamanou, I., \&Vafeas, N. (2005). The association between corporate boards, audit committees, and management earnings forecasts: An empirical analysis. Journal of Accounting Research, 43(3), 453-486.

Khanchel, I. (2007). Corporate governance: measurement and determinant analysis. Managerial Auditing Journal, 22(8), 740-760.

Khlif, H., \& Samaha K. (2016). Audit committee activity and internal control quality in Egypt: Does external auditor's size matter?. Managerial Auditing Journal, 31(3), 269-289.

Krishnan, G. V., \& Visvanathan, G. (2008). Does the SOX definition of an accounting expert matter? The association between audit committee directors' accounting expertise and accounting conservatism. Contemporary Accounting Research, 25(3), 827-857.

Krishnan, J. (2005). Audit committee quality and internal control: an empirical analysis. The Accounting Review, 80(2), 649-675.

Lee, G., \& Fargher, N. L. (2018). The role of the audit committee in their oversight of whistle-blowing. Auditing: A Journal of Practice \& Theory, 37(1), 167-189.

Lin, J. W., Li, J. F., \& Yang, J. S. (2006). The effect of audit committee performance on earnings quality. Managerial Auditing Journal, 21(9), 921-933.

Loebbecke, J., Eining, M., \& Willingham, J. (1989). Auditors' experience with [28] material irregularities: frequency, nature, and delectability. Auditing: A Journal of Practice \& Theory, 9(1), 1-28.

McMullen, D. A., \& Raghunandan, K. (1996). Enhancing audit committee effectiveness. Journal of Accountancy, 182(2), 79.

Menon, K., \& Williams, J. D. (1994). The use of audit committees for monitoring. Journal of Accounting and Public Policy, 13(2), 121-139.

Pearce, J. A., \& Zahra, S. A. (1992). Board composition from a strategic contingency perspective. Journal of Management Studies, 29(4), 411-438.

Peasnell, K. V., Pope, P. F., \& Young, S. (2001). The characteristics of firms subject to adverse rulings by the Financial Reporting Review Panel. Accounting and Business Research, 31(4), 291-311. 


\section{Macrothink}

International Journal of Accounting and Financial Reporting

ISSN 2162-3082

2018, Vol. 8, No. 4

Pfeffer, J., \& Salancik, G. R. (1978). The external control of organizations: A resource dependence perspective. New York: Harper \& Row.

Pucheta-Martínez, M. C., \& De Fuentes, C. (2007). The impact of audit committee characteristics on the enhancement of the quality of financial reporting: An empirical study in the Spanish context. Corporate Governance: An International Review, 15(6), 1394-1412.

Rabab'ah, M., Al-Sir, O., \& Alzoubi, A. (2017). The Impact of the audit committees' properties on the quality of the information in the banking financial reports: a survey on Saudi commercial banks. International Business Research, 10(11), 175-192.

Rainsbury, E. A., Bradbury, M., \& Cahan, S. F. (2009). The impact of audit committee quality on financial reporting quality and audit fees. Journal of Contemporary Accounting and Economics, 5(1), 20-33.

Reddy, K., Locke, S., \& Scrimgeour, F. (2010). The efficacy of principle-based corporate governance practices and firm financial performance: An empirical investigation. International Journal of Managerial Finance, 6(3), 190-219.

Saleh, N. M., Iskandar, T. M., \& Rahmat, M. M. (2007). Audit committee characteristics and earnings management: evidence from Malaysia. Asian Review of Accounting, 15(2), 147-163.

Song, J., \& Windram, B. (2004). Benchmarking audit committee effectiveness in financial reporting. International Journal of Auditing, 8(3), 195-205.

Uzun, H., Szewczyk, S. H., \& Varma, R. (2004). Board composition and corporate fraud. Financial Analysts Journal, 60(3), 33-43.

Vafeas, N. (1999). Board meeting frequency and firm performance. Journal of Financial Economics, 53(1), 113-142.

Xie, B., DavidsonIII, W. N., \&DaDalt, P. J. (2003). Earnings management and corporate governance: The role of the board and the audit committee. Journal of Corporate Finance, 9(3), 295-316.

\section{Copyright Disclaimer}

Copyright for this article is retained by the author(s), with first publication rights granted to the journal.

This is an open-access article distributed under the terms and conditions of the Creative Commons Attribution license (http://creativecommons.org/licenses/by/4.0/) 